\title{
Lithium Chloride Sensitivity in Yeast and Regulation of Translation
}

\author{
Maryam Hajikarimlou ${ }^{1}{ }^{\mathbb{D}}$, Kathryn Hunt ${ }^{1}$, Grace Kirby ${ }^{1}$, Sarah Takallou ${ }^{1}$, \\ Sasi Kumar Jagadeesan ${ }^{1}$, Katayoun Omidi ${ }^{1}$, Mohsen Hooshyar ${ }^{1}$, Daniel Burnside ${ }^{1}$, \\ Houman Moteshareie ${ }^{1}$, Mohan Babu ${ }^{2}$, Myron Smith ${ }^{1}$, Martin Holcik ${ }^{3}$ D , Bahram Samanfar ${ }^{1,4}{ }^{(D)}$ \\ and Ashkan Golshani ${ }^{1, *}$ \\ 1 Department of Biology and Ottawa Institute of Systems Biology, Carleton University, \\ Ottawa, ON K1S 5B6, Canada; Maryamhajikarimlou@cmail.carleton.ca (M.H.); \\ KathrynHunt3@cmail.carleton.ca (K.H.); GraceKirby@cmail.carleton.ca (G.K.); \\ SaraTakalloo@cmail.carleton.ca (S.T.); sasikumarjagadeesan@cmail.carleton.ca (S.K.J.); \\ KatayounOmidi@cmail.carleton.ca (K.O.); Mohsen.Hooshyar@Carleton.ca (M.H.); \\ daniel.burnside@carleton.ca (D.B.); houman.moteshareie@carleton.ca (H.M.); \\ MyronSmith@cunet.carleton.ca (M.S.); bahram.samanfar@canada.ca (B.S.) \\ 2 Department of Biochemistry, Research and Innovation Centre, University of Regina, \\ Regina, SK S4S 0A2, Canada; mohan.babu@uregina.ca \\ 3 Department of Health Sciences, Carleton University, Ottawa, ON K1S 5B6, Canada; \\ MartinHolcik@cunet.carleton.ca \\ 4 Agriculture and Agri-Food Canada, Ottawa Research and Development Centre (ORDC), \\ Ottawa, ON K1Y 4X2, Canada \\ * Correspondence: Ashkan_Golshani@carleton.ca
}

Received: 21 May 2020; Accepted: 7 August 2020; Published: 10 August 2020

\begin{abstract}
For decades, lithium chloride $(\mathrm{LiCl})$ has been used as a treatment option for those living with bipolar disorder (BD). As a result, many studies have been conducted to examine its mode of action, toxicity, and downstream cellular responses. We know that $\mathrm{LiCl}$ is able to affect cell signaling and signaling transduction pathways through protein kinase $C$ and glycogen synthase kinase- 3 , which are considered to be important in regulating gene expression at the translational level. However, additional downstream effects require further investigation, especially in translation pathway. In yeast, $\mathrm{LiCl}$ treatment affects the expression, and thus the activity, of $P G M 2$, a phosphoglucomutase involved in sugar metabolism. Inhibition of $P G M 2$ leads to the accumulation of intermediate metabolites of galactose metabolism causing cell toxicity. However, it is not fully understood how $\mathrm{LiCl}$ affects gene expression in this matter. In this study, we identified three genes, NAM7, PUS2, and RPL27B, which increase yeast $\mathrm{LiCl}$ sensitivity when deleted. We further demonstrate that NAM7, PUS2, and RPL27B influence translation and exert their activity through the $5^{\prime}$-Untranslated region (5'-UTR) of PGM2 mRNA in yeast.
\end{abstract}

Keywords: lithium chloride; mode of activity; toxicity; bipolar disorder; side effects; gene expression; yeast; translation

\section{Introduction}

Bipolar disorder (BD) is known to be associated with dysregulated signaling pathways. For the past few decades lithium chloride $(\mathrm{LiCl})$ has been a key treatment option for those living with $\mathrm{BD}$, because of its neuroprotective effects [1,2]. It has been used as a psychotropic drug and has anti-suicidal and anti-depressant effects in BD patients $[3,4]$ by possibly targeting miRNAs regulating proteins involved in mood stability [5]. LiCl plays a role in two key signal transduction pathways including 
Protein Kinase C and Glycogen Synthase Kinase-3, both of which are involved in neurodevelopment and neuronal plasticity [1]. It has been shown to have neuroprotection effects, protecting neurons against apoptosis and disturbing other pathways including cell proliferation, apoptosis, cell fate, and translation [5-8].

As a monovalent cation which targets the nervous system, $\mathrm{LiCl}$ has been studied as a potential treatment for Alzheimer's disease (AD), Parkinson's disease, and Huntington's disease [7,9]. Increased plaques and tangles in the dopaminergic regions leads to increased cell death, a well-known characteristic of $\mathrm{AD}$ [1]. The efficacy of $\mathrm{LiCl}$ as a treatment for $\mathrm{AD}$ appears to be linked to $\mathrm{LiCl}^{\prime} \mathrm{s}$ ability to decrease levels of amyloid $\beta$ and decrease phosphorylation of the tau protein [10]. Although much is known about the activity of $\mathrm{LiCl}$, it is still unclear how it affects the cell at the molecular level. The influence of $\mathrm{LiCl}$ on gene expression and its secondary effects are also not well-understood. It has been observed that, after long term treatment of $\mathrm{BD}$ patients with $\mathrm{LiCl}$, the expression of genes involved in the phosphoinositide/Protein Kinase C (PI/PKC) signaling cascade are disturbed. As a result, this causes disruption in function of nerve cells [7,11-13], renal cells, and liver cell damages [2]. Understanding how $\mathrm{LiCl}$ is regulating the expression of specific genes related to these pathways, as well as others, requires further investigation.

Yeast is particularly sensitive to $\mathrm{LiCl}$ when galactose is used as a sugar source. This is because $\mathrm{LiCl}$ alters the expression and activity of $P G M 2$, a phosphoglucomutase which mediates the entry of galactose into glycolysis [14,15]. PGM2 also converts glucose-1-P to glucose-6-P and, if inhibited, it leads to accumulation of intermediate metabolites causing toxicity in yeast cells [16]. When $\mathrm{LiCl}$ is added to galactose media, yeast cell growth is severely reduced due to impaired glycolysis. $\mathrm{LiCl}$ also reduces the levels of uridine diphosphate glucose (UDP-glucose) and disrupts associated pathways in the presence of glucose. Other studies have also suggested that $\mathrm{LiCl}$ might inhibit RNA processing enzymes and rapidly reduce expression of ribosomal protein genes [17,18]. This results in a decreased number of mature mRNAs in the cytoplasm [17], suggesting inhibition at translational level.

Sensitivity of yeast to $\mathrm{LiCl}$ has also been connected to transport kinetics and cellular metabolism $[19,20]$. Other studies have reported that $\mathrm{LiCl}$ effects sporulation in yeast by delaying the process [19]. Zhao et al. [20] found 25 genes involved in sporulation and 35 gene in membrane docking and fusion that, when deleted, yeast showed increased sensitivity to LiCl. Among them was HAL1 gene that encodes a halotolerant protein kinase known to be crucial for integrity of vacuolar protein sorting pathway (VPS). In the same study, it was shown that $\mathrm{LiCl}$ can also affect ion homeostasis. On glucose media, addition of $100 \mathrm{mM} \mathrm{LiCl}$ reduced transcription rate in yeast [19] and in Candida albicans [21]. It is proposed that the sensitivity of $C$. albicans deletion mutant for $M A F 1$, a repressor of RNA polymerase III might be due to $\mathrm{LiCl}$ targeting transcription [21]. Effect of $\mathrm{LiCl}$ on inositol inhibition in yeast was investigated by Lopez et al. [22]. The authors showed that the yeast inositol monophosphatase is targeted by $\mathrm{LiCl}$, affecting calcium signaling and inositol biosynthesis [22].

Other studies suggest that $\mathrm{LiCl}$ inhibits the initial steps of protein synthesis. One study has demonstrated that $\mathrm{LiCl}$ may be able to disrupt the association between the translation initiation factor eIF4A, an RNA helicase, and the rest of the translational machinery, resulting in impaired translation initiation [14]. However, this was not observed in yeast growing on glucose media. In the same study, it was shown that the over-expression of eIF4A was able to revert the inhibition of translation due to $\mathrm{LiCl}$ [14]. In a recent investigation, we showed a connection between $\mathrm{LiCl}$ and translation of structured mRNAs [23].

Large scale sensitivity analysis of yeast for other compounds including cobalt and lead has also been investigated [24,25]. It was reported that yeast sensitivity to cobalt is likely because of the effect of cobalt on oxidative stress response and unfold protein response pathways [25]. In another study, it was shown that lead and cadmium seem to target the metabolism and cellular transport processes in yeast [24].

In the current study, we observed that the deletion of three yeast genes, NAM7, PUS2, and RPL27B increased the sensitivity of yeast cells to $\mathrm{LiCl}$. These genes have never been studied in cell responses 
linked to $\mathrm{LiCl}$. NAM7 is an important gene involved in efficient termination of translation, especially in nonsense-mediated mRNA decay. This gene codes for an RNA helicase, which binds to the small ribosomal subunit, controlling decay for a specific subset of mRNAs. PUS2 is involved in tRNA modification in the mitochondria and also pseudouridylation of some nuclear mRNAs. And lastly, $R P L 27 B$ encodes for the large ribosomal subunit, but it is not known if it is involved in translation regulation. In this study, we demonstrate that deletion of yeast genes NAM7, PUS2, and RPL27B increases sensitivity of yeast to $\mathrm{LiCl}$. Follow-up genetic investigations suggest involvement of these genes in yeast $\mathrm{LiCl}$ sensitivity through their effect on translation of PGM2.

\section{Results}

\subsection{Deletion of NAM7, PUS2, and RPL27B Increases Yeast Sensitivity to Lithium Chloride}

Chemical sensitivity of mutant strains under treatment of a target compound is an investigation tool that allows us to determine the targeted pathways of the compound and allows observation into the effects on the cell at a molecular level [26-28]. While investigating yeast gene deletion mutants that are sensitive to $\mathrm{LiCl}$, we identified three gene deletion mutants: NAM7, PUS2, and RPL27B which showed increased sensitivity to $\mathrm{LiCl}$ (Figure 1B), compared to control media without $\mathrm{LiCl}$ treatment (Figure 1A). In the spot test assay, we demonstrate that deletion of TIF2 (eIF4A) causes increased sensitivity to $10 \mathrm{mM} \mathrm{LiCl}$ when grown in media with galactose as the carbon source. Deletion of NAM7, PUS2, and RPL27B showed dramatic growth reduction in the same manner (Figure 1B), suggesting sensitivity to $\mathrm{LiCl}$. Reintroduction of the deleted genes back into the chromosome of the corresponding gene deletion mutants reversed this growth reduction, further connecting the observed phenotypes to the deleted gene (Supplementary Figure S1). We also tested to see the sensitivity of yeast strains to LiCl using glucose as the carbon source; however, no significant toxicity was observed (data is not shown).

It has been previously shown that over-expression of TIF2 reverts the toxicity of sensitive strains to $\mathrm{LiCl}$ [14]. To see if our candidate genes would revert $\mathrm{LiCl}$ sensitivity in the same manner, we transferred over-expression plasmid of our candidate genes into corresponding deletion strains spotted on media containing $10 \mathrm{mM} \mathrm{LiCl}$. When the plasmids were introduced to the mutants, the fitness of the strains was recovered, proposing they may have similar function as eIF4A in the cell (Figure 1C). The molecular activity of NAM7, PUS2, and RPL27B has never been connected to LiCl sensitivity and the molecular pathways related to that, making them interesting targets for further investigation.

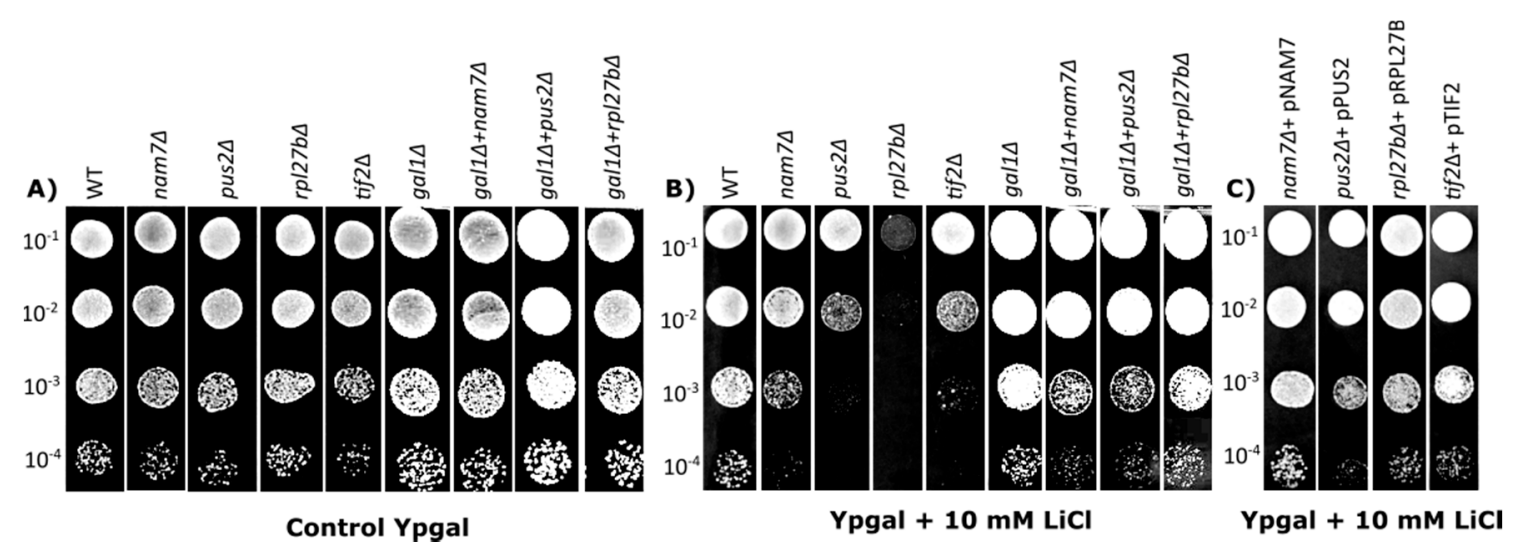

Figure 1. Lithium chloride $(\mathrm{LiCl})$ sensitivity analysis for different yeast strains using spot test analysis. In (A-C) yeast cells were serially diluted as indicated $\left(10^{-1}\right.$ to $\left.10^{-4}\right)$ and spotted on Ypgal (Yeast extract, Peptone, and Galactose) media with or without $\mathrm{LiCl}(10 \mathrm{mM})$. In (A,B), nam7 $\Delta$, pus $2 \Delta$, and $r p l 27 b \Delta$ show less growth under $\mathrm{LiCl}$ treatment compared to wild type (WT). (C) Over-expression of target gene in their corresponding deletion mutants reverted cell sensitivity to $\mathrm{LiCl}(10 \mathrm{mM})$. Each experiment was repeated at least three times $(n \geq 3)$ with similar outcomes. 
These findings were confirmed with colony count measurement analysis, providing a quantitative approach (Figure 2). In this experiment, the number of colonies seen in the presence of $\mathrm{LiCl}$ in the media is compared and normalized to the number of colonies seen in control media and wild type (WT). Using this data, we were able to calculate the decreased percentage of colonies seen in deletion strains. As seen in Figure 2, deletion of NAM7, PUS2, RPL27B, or TIF2 lead to decreased colony formation.

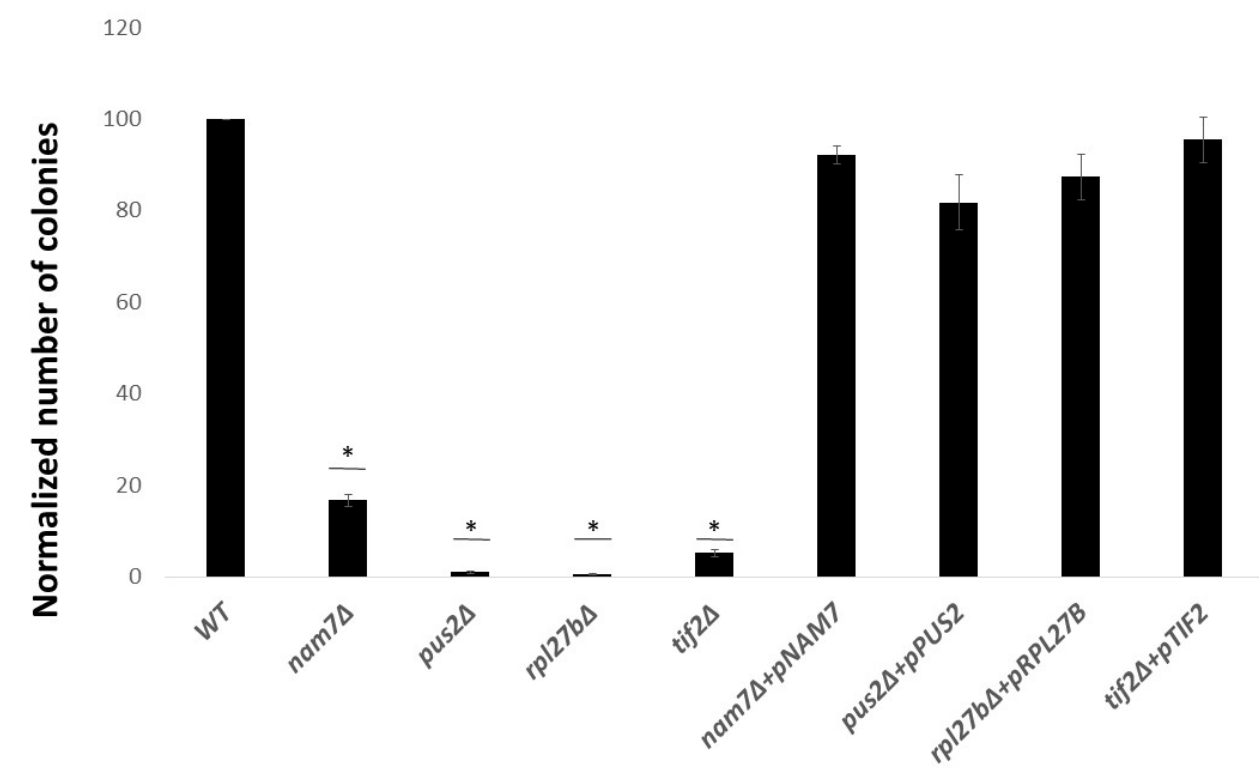

Figure 2. Quantitative analysis of $\mathrm{LiCl}$ sensitivity for different yeast strains. Average number of colonies formed for different yeast strains in the presence of $\mathrm{LiCl}(10 \mathrm{mM})$ were normalized to that for WT strain. nam $7 \Delta, p u s 2 \Delta$, and $r p l 27 b \Delta$ show less colonies under $\mathrm{LiCl}$ treatment. Over-expression of target genes in their corresponding deletion mutants reverted cell sensitivity to $\mathrm{LiCl}$. ${ }^{*}(p$-value $\leq 0.05)$ represent statistically significant results compared to WT. Data represents the average from three independent experiments and error bars represent standard deviation.

LiCl targets $P G M 2$ expression which leads to an accumulation of galactose intermediate metabolites, which becomes toxic for yeast cells including galactose-1-p $[14,15,29]$. In yeast, GAL1 is the galactokinase that phosphorylates $\alpha$-D-galactose to $\alpha$-D-galactose-1-phosphate in the first step of galactose catabolism. The PGM2 enzyme facilitates the entry of galactose into glycolysis and converts glucose-1-phosphate to glucose-6-phosphate. To investigate the influence of NAM7, PUS2, and RPL27B on LiCl toxicity through galactose metabolism, we generated double gene deletions for NAM7, PUS2, and RPL27B with the GAL1 gene. We observed that when GAL1 was deleted, double mutant cells did not show sensitivity to $\mathrm{LiCl}$ treatment (Figure 1B).

\subsection{NAM7, PUS2, and RPL27B Regulate the Expression of PGM2 at the Level of Translation}

Since altered expression of $P G M 2$ has been seen in the presence of $\mathrm{LiCl}$ [29], we examined to see if NAM7, PUS2, or RPL27B would affect PGM2 expression at the translation level. Pgm2p was tagged with GFP and western blot analysis was done to see if any of the three genes altered PGM2 expression (Figure 3A). When cells were exposed to $10 \mathrm{mM} \mathrm{LiCl}$, deletion of any three of the genes resulted in reduced protein levels of Pgm2p compared to WT. When cells were not exposed to $\mathrm{LiCl}$, deletion of NAM7, PUS2, or RPL27B showed no significant difference in cell fitness.

To see the impact of NAM7, PUS2, or RPL27B on PGM2 transcription, qRT-PCR was performed to measure the mRNA content of PGM2. As seen in Figure 3B, deletion of NAM7, PUS2, or RPL27B did not significantly alter $P G M 2$ mRNA levels on control media compared to WT. The mRNA content of PGM2 increased in cells treated with $\mathrm{LiCl}$ but showed no significant difference between mutant strains and WT. This suggests that these genes do not impact PGM2 at transcriptional level. Thus, this would 
imply that NAM7, PUS2, or RPL27B affect expression of Pgm2p at the protein level. These results are in agreement with a previous study by Sofola-Adesakin [7], who demonstrated that $\mathrm{LiCl}$ impaired gene expression during protein synthesis and not during transcription [7].
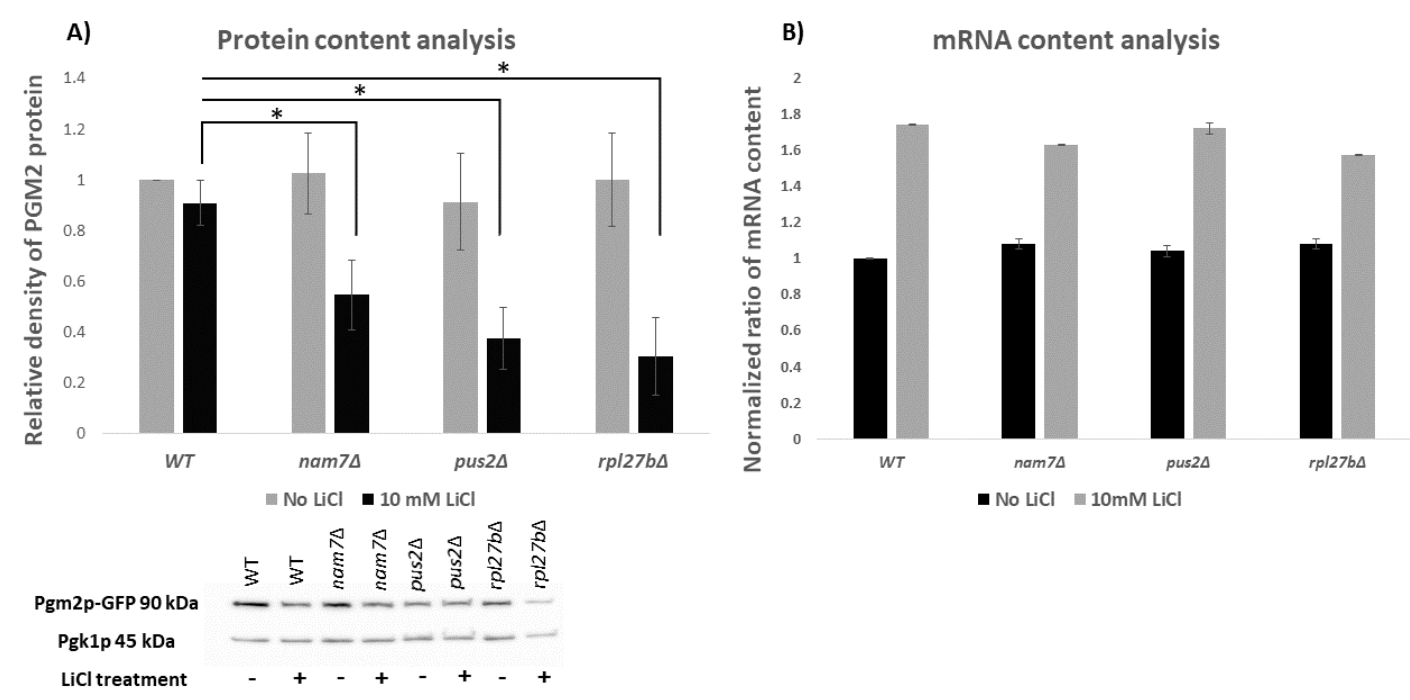

Figure 3. Protein and mRNA content analysis. (A) Protein content analysis of Pgm2p-GFP protein in deletion yeast strains for $n a m 7 \Delta$, pus $2 \Delta$, and $r p l 27 b \Delta$. Western blot analysis was used to measure the protein content for Pgm2p-GFP protein in the absence or presence of $\mathrm{LiCl}(10 \mathrm{mM})$. Pgk1p was used as housekeeping gene and the values are normalized to that. (B) mRNA content analysis of PGM2 in $n a m 7 \Delta$, pus $2 \Delta$, and $r p l 27 b \Delta$. qRT-PCR was used to evaluate the content of PGM2 mRNA in yeast gene deletion mutants related to WT strain and normalized to PGK1 mRNA levels. Each experiment was repeated at least three times. ${ }^{*}(p$-value $\leq 0.05)$ represent statistically significant results compared to WT. Error bars represent standard deviation.

2.3. Translation of $\beta$-Galactosidase Reporter mRNA with a Hairpin Structure Is Altered by Deletion of NAM7, PUS2, and RPL27B

The 5'-UTR of PGM2 mRNA has a highly structured region [30] (Figure S2). PGM2 expression is severely reduced in the absence of translation initiation helicase TIF2, a protein responsible for unwinding mRNA structures during translation [14]. Since we observed that NAM7, PUS2, and $R P L 27 B$ are likely to function in the translation pathway, we decided to examine if these genes are possibly impacting translation of highly structured mRNAs. For this experiment, we inserted $5^{\prime}$-UTR of PGM2 in front of a LacZ expression cassette of p416 plasmid (pPGM2). From here, pPGM2 was then transformed into deletion mutant strains of our candidate genes and WT. $\beta$-galactosidase activity was measured as a reference for translation activity (Figure 4A). It was shown that translation activity significantly decreased in Nam $7 \Delta, P u s 2 \Delta$, and $R p l 27 b \Delta$ carrying plasmid with hairpin when compared to translation activity with control plasmid (Figure $4 \mathrm{~B}$ ). 

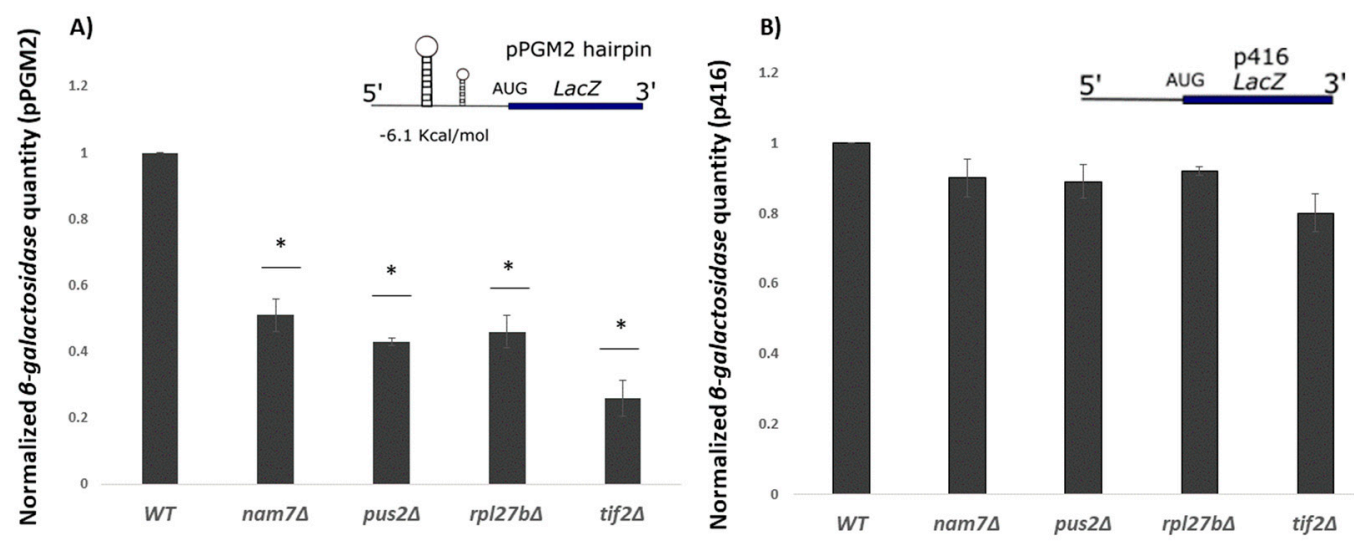

Figure 4. $\beta$-galactosidase expression analysis in different yeast strains. (A) Activities from $\beta$-galactosidase mRNAs that carry 5'-UTR of PGM2 mRNA (pPGM2) upstream of LacZ reporter was reduced in nam7 $\Delta$, pus $2 \Delta$, and $r p l 27 b \Delta$ strains. Strains carrying low complexity regions upstream of LacZ reporters $\mathrm{p} 416$ (B) did not show as significant reductions in $\beta$-galactosidase activity. Values are normalized to that for WT which resulted in average $\beta$-galactosidase values of $38.1 \mathrm{U}$ and $407.5 \mathrm{U}$ for pPGM2 and p416 constructs, respectively. Each experiment was repeated at least three times $(n \geq 3)$ and error bars represent standard deviation. * represents statistically significant results ( $p$-value $\leq 0.05$ ) compared to the WT. $t$-test analysis was used to compare differences. The insets represent schematic reporter mRNA structures.

To investigate whether this effect is specific to the $5^{\prime}$-UTR of PGM2 mRNA, we used a second construct with a strong hairpin structure on its 5'-UTR (p281-4) [31]. As a control, we used p281, which lacks a secondary structure [31]. We observed that $\beta$-galactosidase activity was reduced in p281-4 when NAM7, PUS2, or RPL27B was deleted, whereas, for $\mathrm{p} 281$, there was no significant difference between the mutants and WT (Figure 5A,B). These results demonstrate that the tested genes do not appear to affect translation of mRNAs lacking structured regions and exert their activities specifically on structured mRNAs.

Since NAM7, PUS2, and RPL27B impacted translation of structured reporter mRNAs, we wanted to see if they were able to impact translation of other naturally structured mRNAs compared to the previous ones which were designed by software. For this purpose, we designed two $\beta$-galactosidase mRNA reporters with different complex RNA structures: pTAR and pRTN. pTAR has the $5^{\prime}$-UTR of the HIV-tar1 gene, which has a strong hairpin loop, while pRTN has the $5^{\prime}$-UTR of the FOAP-11 gene, which has a highly structured region [32,33]. When NAM7, PUS2, or RPL27B were deleted, levels of $\beta$-galactosidase expression were significantly reduced (Figure $5 C, D$ ). 

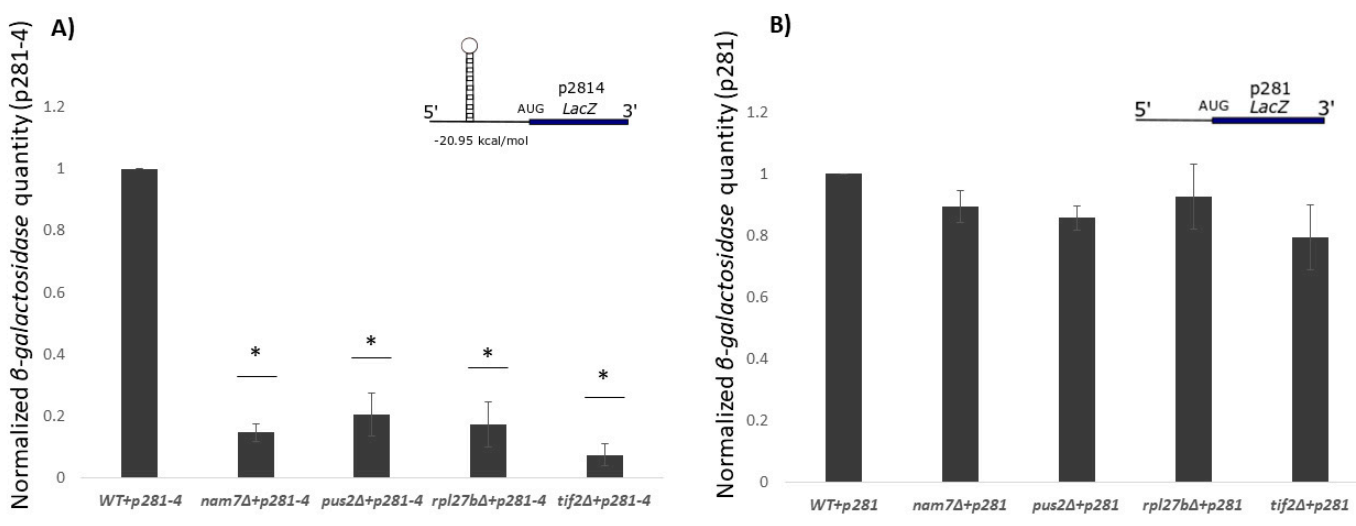

C)

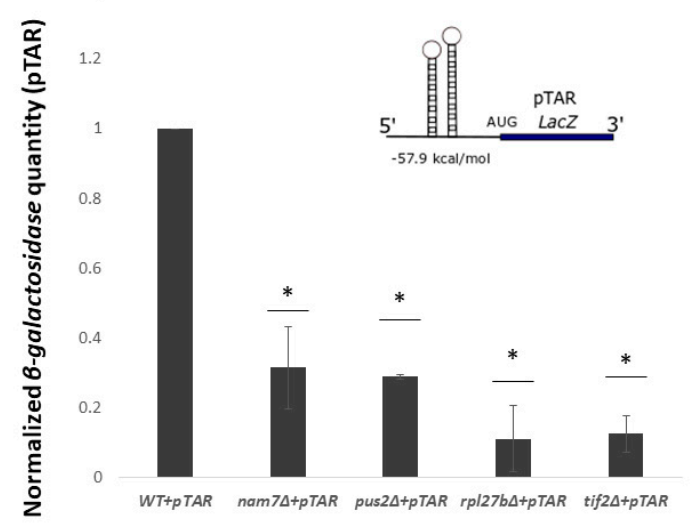

D)

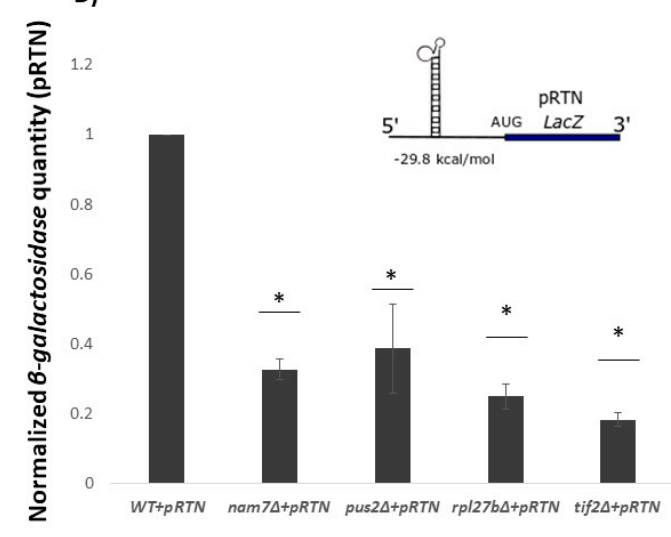

Figure 5. $\beta$-galactosidase expression analysis in different yeast strains. (A) Activities from $\beta$-galactosidase mRNAs that carry a strong hairpin structure (p281-4) upstream of a LacZ reporter were highly reduced in nam $7 \Delta$, pus $2 \Delta$, and hal1 $\Delta$ strains. (B) Our control plasmid (p281) with no inhibitory structure did not show reductions in $\beta$-galactosidase activity. pTAR (C) and pRTN (D) constructs contain the highly structured 5'-UTR of HIV-tar1 and FOAP-11 genes, respectively, in front of the $\beta$-galactosidase reporter mRNA showed significant reduction in mutant strains. Values are normalized to that for WT, which resulted in average $\beta$-galactosidase values of $14.1 \mathrm{U}$ and $37.9 \mathrm{U}$ for pRTN and p416 constructs, respectively. Each experiment was repeated at least three times $(n \geq 3)$ and error bars represent standard deviation. * represent statistically significant results $(p$-value $\leq 0.05)$ compared to the WT. $t$-test analysis ( $p$-value $\leq$ $0.05)$ was used to compare differences. The insets represent schematic reporter mRNA structures.

2.4. Genetic Interaction Analysis Further Connects the Activity of NAM7, PUS2, and RPL27B to Protein Biosynthesis

Genetic interaction (GI) analysis assumes that parallel pathways allow for plasticity and tolerance against random deleterious mutations, protecting cells and maintaining cell homeostasis if one gene is deleted or mutated in a pathway [34]. This means that a gene in one pathway can compensate for the lack of gene activity in a parallel pathway, allowing the cell to survive. Accordingly, when two genes in parallel pathways are deleted, cell fitness decreases (sickness) or the cell dies (lethality). As a result, we assert that the two genes are genetic interactors, or in other words, they are functionally working in parallel pathways. These aggravating interactions are also known as negative genetic interactions (nGIs). nGIs are useful in many studies to understand gene function and pathway crosstalk $[26,35,36]$.

Analysis of GIs in yeast is done by mating two types of yeast: $\alpha$-mating type (Mat $\alpha$ ), and a-mating type (Mat a). Mat " $\alpha$ " carries the target gene deletion, which is crossed with Mat "a", an array of single gene deletions to produce double gene deletions [37]. Fitness of double deletions is measured using colony size assessment [38]. Using this method, we made double deletions for each of our three 
query genes NAM7, PUS2, and RPL27B with nearly 1000 other genes to screen for possible genetic interactions. This experiment included a random set of 304 genes as controls.

We observed several interesting nGIs with NAM7, including PRP22, TIF2, GCD11, and PRT1. PRP22 is a DEAH-box RNA helicase, TIF2 codes for the translation initiation factor eIF4A, GCD11 forms part of the small subunit of eIF2, and PRT1 is the subunit of eIf3. Other interacting genes involved in translation initiation are YGR054W and HCR1 (Figure 6).

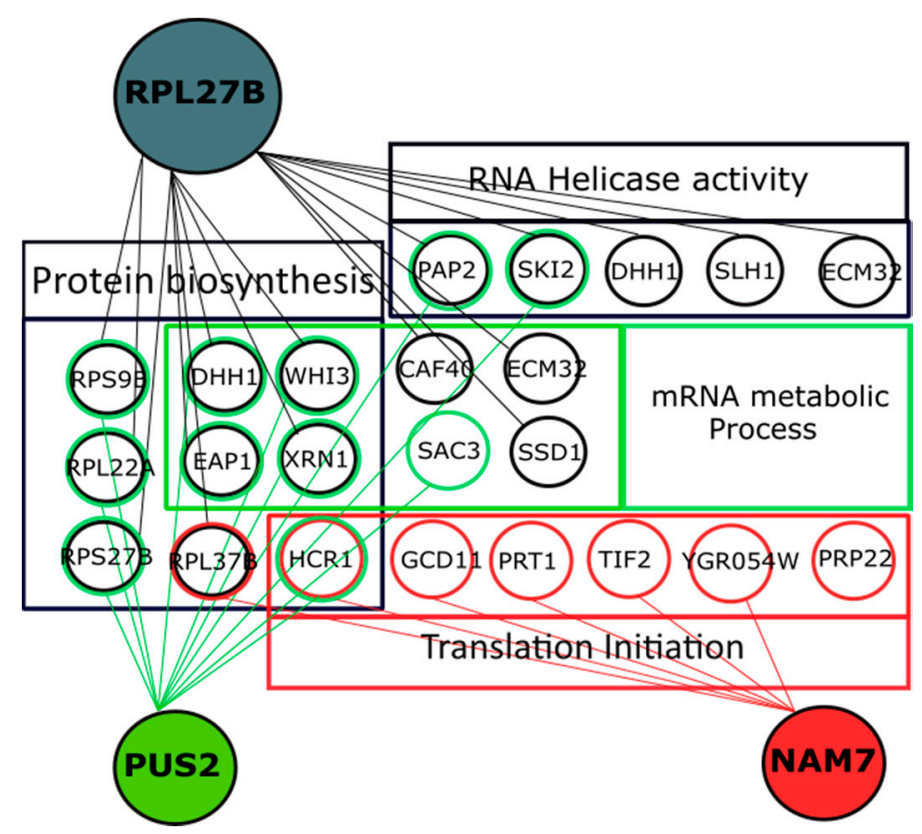

Figure 6. Negative genetic interactions (nGIs) for NAM7, PUS2, and RPL27B. Our data shows a cluster of interactors involved in protein biosynthesis pathway for NAM7 $\left(p=1.6 \times 10^{-7}\right)$, PUS2 $\left(p=4 \times 10^{-8}\right)$, and RPL27B $\left(p=1.2 \times 10^{-5}\right)$. PAP2, SKI2, RPS9B, RPL37B, RPS27B, RPL22A, DHH1, EAP1, WHI3, HCR1, and $X R N 1$ are mutual hits shared between two target genes. Circles represent genes, lines represent nGIs identified in this study.

PUS2 interacted with DHH1, EAP1, and HCR1 among others. DHH1 codes for an ATP-dependent RNA helicase, EAP1 codes for an eIF4E-associated protein, and HCR1 codes for a subunit of the eIF3 translation initiation factor, which is also important in binding of initiation factors to $40 \mathrm{~S}$ subunit and AUG recognition along with HCR1 as an RNA recognition motif [39]. Many of PUS2 nGIs were involved with ribosomal structural proteins (Figure 6).

As expected, RPL27B interacted with a number of translation genes (Figure 6). This included DHH1, EAP1, SLH1, and SKI2, which have RNA helicase activity, as well as ECM32, which has DNA helicase activity and is also involved in modulating translation termination.

Comparing the nGI profiles for NAM7, PUS2, and RPL27B we noticed some interesting common hits. HCR1 is a subunit of eIF3 and is known to be important for scanning efficiency specially in cooperation with DED1 (RNA helicase) on long 5'-UTRs [40] and binding with DHX29 in human cells [41]. PRT1 is also crucial in recognition of the right start codon. During scanning, PRT1 inhibits leaky scanning by promoting the stability of ribosomes on mRNAs possibly by changing its conformation $[42,43]$. XRN1 is known to be involved in mRNA decay and transcription regulation, but recently it was proposed that it might also play a role in translation pathway by regulating translation of specific mRNAs through binding to eIF4F complex, a translation initiation complex [44]. DED1 is an ATP-dependent helicase that associates with eIF4A to regulate translation initiation $[45,46]$. Methylation of DED1 strengthens its binding to eIF4A and to XRN1 [47], suggesting its potential effect on translation regulation. XRN1 was also proposed to interact with another helicase, DHH1, in yeast 
to control translation by decapping mRNAs for degradation [48,49]. P54 (homologue of DED1 in humans) was shown to be important in localization and assembly of P-bodies in the cell [48].

The comparison of this data to the published nGIs in Saccharomyces Genome Database (SGD) shows an expected degree of overlap. For example, for NAM7, except for an observed nGI with YGR054W in the current study, other observed nGIs overlap with the reported interactions. This provides further confidence for the validity of our observations.

Another form of nGIs, called conditional nGI, can be studied under sub-inhibitory concentration of chemicals. It is used to investigate possible candidate gene functions that are activated under a specific condition $[27,50]$. For this experiment, we studied nGIs for NAM7, PUS2, and RPL27B under a mild sub-inhibitory concentration of $\mathrm{LiCl}(3 \mathrm{mM})$. Shown in Figure 7, new nGIs were observed for our candidate genes. The new interactions hinted to new conditional functions for NAM7, PUS2, and $R P L 27 B$ in regulation of translation. We observed a number of common interactors between the three query genes including $B C K 1, C T K 1$, and MCK1. $B C K 1$ is important in negative regulation of translation under stress conditions. It is involved in deadenylation and decapping of mRNAs to be degraded in connection with DHH1 [51-54]. On the other hand, CTK1 is a conserved kinase that phosphorylates RPS2p, one of the components of small ribosomal subunit. It affects translation fidelity during elongation, as well as phosphorylation of other translation initiation factors, including eIF4A, eIF5, eIF4G, and eIF3 [55,56]. MCK1 is involved in phosphorylation-dependent protein degradation, among other roles.

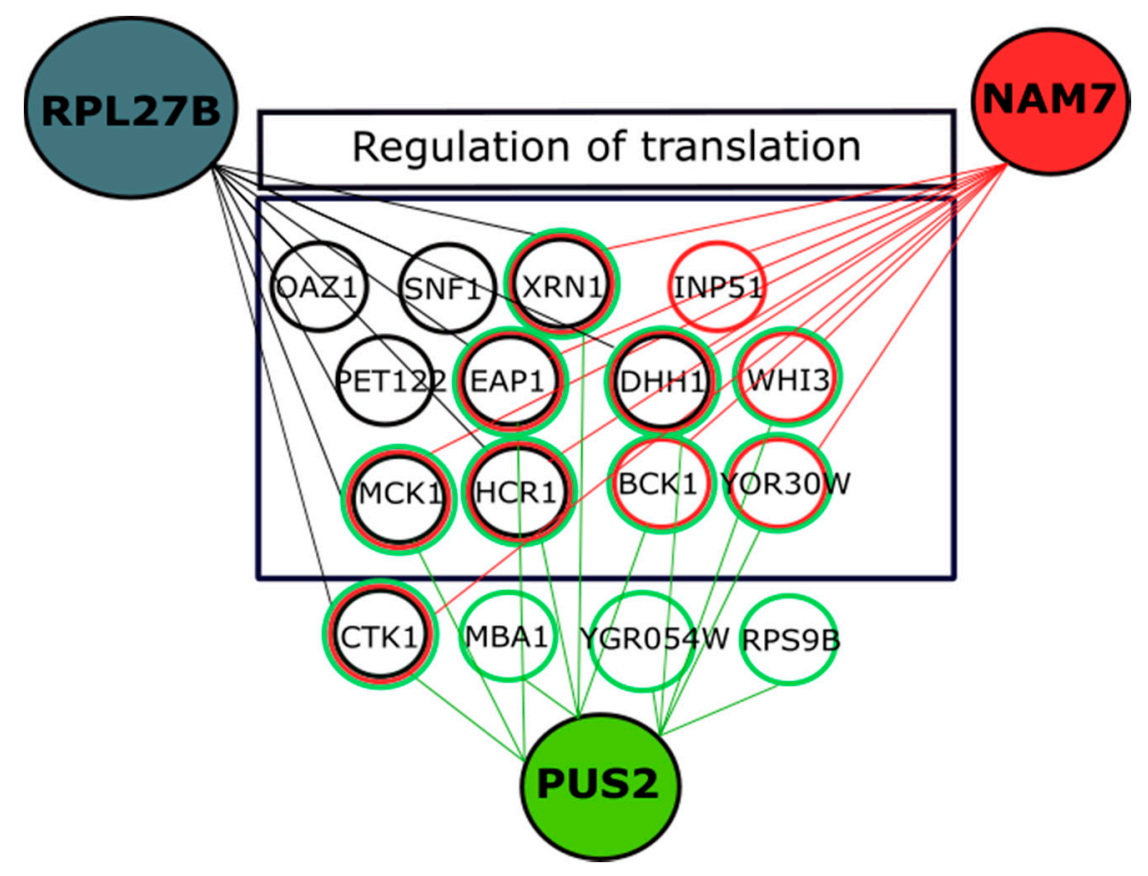

Figure 7. Conditional nGIs for NAM7, PUS2, and RPL27B under $3 \mathrm{mM}$ concentration of LiCl. Our data shows a mutual Gene Ontology (GO) term enrichment for translation regulation genes for NAM7 $(p=$ 0.00037), PUS2 $\left(p=1.1 \times 10^{-6}\right)$, and RPL27B $\left(p=1 \times 10^{-6}\right) . B C K 1, M C K 1, C T K 1, E A P 1, X R N 1$, and $\mathrm{DHH} 1$ are mutual nGIs between the three quarry genes. Circles represent genes and lines represent nGIs identified in this study.

Phenotypic Suppression Array (PSA) analysis focuses on another form of interaction where over-expression of one gene compensates for the absence of another gene, under a drug treatment $[26,36,57,58]$. Here, we treated the arrays of mutant strains with $10 \mathrm{mM} \mathrm{LiCl}$, and, consequently, some showed sensitivity. Then, we were able to revert $\mathrm{LiCl}$ sensitivity in a number of deletions by introducing over-expression plasmid of NAM7, PUS2, and RPL27B. Interestingly, over-expression of NAM7, PUS2, and RPL27B compensated for the sensitivity of four mutual gene 
deletions ITT1 $\triangle$, eIF2A $\triangle, E A P 1 \triangle$, and PSK2 $\triangle$ (Figure 8). Eap1 encodes for an eIF4E-associated protein that accelerates decapping of mRNA and negatively regulates translation [53]. ITT1 interacts with the translation release factor eRF3 and modulates the efficiency of translation termination. eRF3 is not only important in regulation of translation termination and cell cycle regulation but also is shown to mediate mRNA decay through interaction with UPF family of proteins that include one of our query genes NAM7 [59]. Itt1p interacts with Mtt1p, an RNA helicase and poly(A) binding protein Pab1p involved in mRNA circularization and ribosome recycling [59,60]. eIF2A deletion also showed sensitivity to $10 \mathrm{mM} \mathrm{LiCl}$ and was reverted by over-expression of NAM7, PUS2, and RPL27B in our experiments. eIF2A, a translation initiation factor, is shown to regulate IRES-mediated translation and because of its physical interaction with Ded1p and eIF4A, it has been suggested to play a role in translation regulation of certain mRNAs [61]. PSK2 is known to be important in regulating both sugar metabolism and translation through phosphorylation of intermediate molecules [62]. In addition, PSK2 is shown to function as a trans-acting factor for translational regulation of mRNAs with upper Open Reading Frames (uORFs), including ROK1 that encodes an RNA helicase [63].

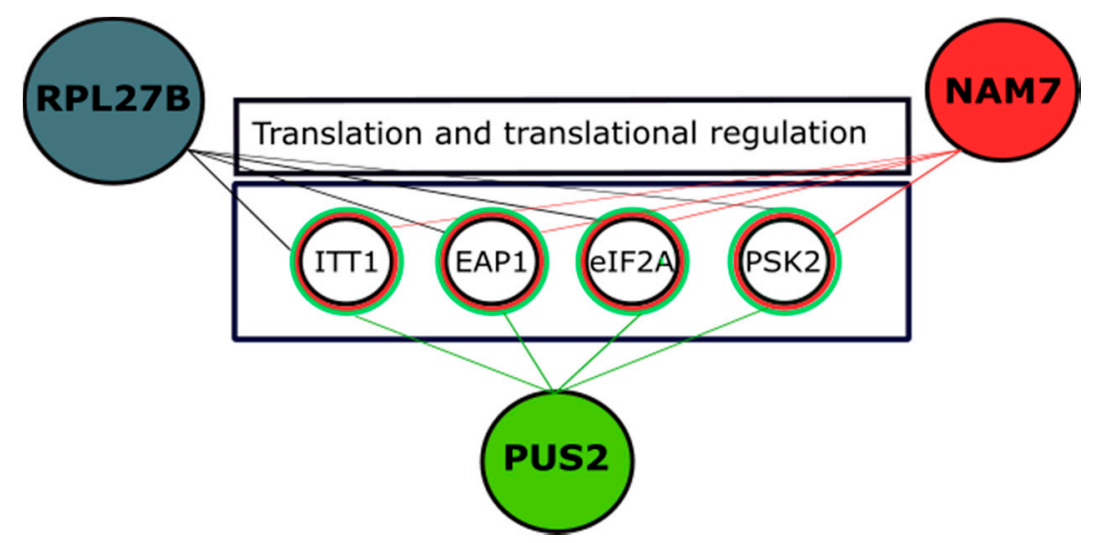

Figure 8. Over-expression of NAM7, PUS2, and RPL27B compensate for the sensitivity of ITT1 $\triangle$, $E A P 1 \triangle, e I F 2 A \triangle$, and PSK2 $\triangle$ to $10 \mathrm{mM} \mathrm{LiC.} \mathrm{EAP1} \mathrm{is} \mathrm{known} \mathrm{to} \mathrm{be} \mathrm{involved} \mathrm{in} \mathrm{negative} \mathrm{regulation} \mathrm{of}$ translation via DHH1 (RNA helicase) and PSK2 is involved in translation regulation of mRNAs with uORFs. eIF2A and ITT1 participate in translation initiation and termination steps, respectively.

\section{Discussion}

Chemical genetic profiling is an investigating tool that enables us to determine not only the genetic targets of a compound, but also the effect of the compound on different genes and pathways. In addition, it can be used as a powerful tool to identify new gene functions $[27,28,64,65]$. Complementary assays can be used to generate the chemical-genetic profiles of various compounds. In the current stud $\mathrm{y}$, we used the yeast nonessential gene knockout library to investigate $\mathrm{LiCl}$ sensitivity. A more inclusive collection of bar-coded yeast strains containing both essential and nonessential genes with decreased abundance of mRNA perturbation (DAmP) is also available to study chemical genetics [66]. Using this approach, it was shown that the protein product of IPP1 genes, a cytoplasmic inorganic pyrophosphatase is specifically inhibited by $\mathrm{NaF}$ [67].

$\mathrm{LiCl}$ has been shown to have a broad effect on the expression of different genes and pathways when used as a therapeutic compound, but its exact mechanism of function is not fully understood. Here, we investigated yeast gene deletion mutant strains for their sensitivity to $\mathrm{LiCl}$ treatment and identified three genes, NAM7, PUS2, and RPL27B that when deleted, their corresponding deletion mutant strains showed increased sensitivity to $\mathrm{LiCl}$. It has been shown that the over-expression of TIF2 that codes for eIF4A, the helicase enzyme involved in translation initiation step, reverts $\mathrm{LiCl}$ sensitivity in yeast cells growing in galactose media [14]. Here, we observed that the over-expression of our candidate genes confer similar phenotypes to that for TIF2, suggesting a linked activity for these gene. The molecular activity of NAM7, PUS2, and RPL27B has not been connected to LiCl sensitivity 
and the molecular pathways related to that, making them interesting targets for investigation. Yeast cells are sensitive to $\mathrm{LiCl}$ treatment due to the accumulation of the galactose intermediate metabolites including galactose-1-p [14,15]. It is suggested that $\mathrm{LiCl}$ targets $P G M 2$, the phosphoglucomutase enzyme, and prevents conversion of glucose-1-phosphate to glucose-6-phosphate by changing its expression [29]. In the current study, we show that NAM7, PUS2, and RPL27B affect PGM2 expression. More specifically, we provide evidence that NAM7, PUS2, and RPL27B affect the translation of PGM2 and different reporter $\beta$-galactosidase mRNAs and that they exert this activity through the structured $5^{\prime}$-UTR regions of the mRNAs. Very recently we reported on the new activity of two additional genes, YTA6 and YPR096C on the translation of structured mRNAs [23]. Identification of new gene functions that affects this process suggests that the translation of structured mRNAs might be more complicated than originally thought. It appears that different factors can contribute to the translation of these mRNAs and that structured on mRNAs are subjected a more complex regulator network.

The effect of NAM7, PUS2, and RPL27B on the translation of structured mRNAs can be explained in different ways. The simplest explanation is that one or more of these factors might have mRNA helicase activities, which can directly contribute to the unwinding of the structured regions of the mRNA. NAM7 is previously reported to have a helicase activity. Therefore, it is likely that the observed activity of NAM7 in the current study might be linked to its reported helicase function. No helicase activities for PUS2 and RPL27B has been previously reported making the direct unwinding of mRNA structures a less likely explanation for their activities. It is possible that one or more of these factors could influence the activity of other complexes with helicase activity. In this fashion they can play an accessory role in the translation of structured mRNAs. RPL27B codes for a ribosomal protein. A possibility is that the ribosomes in the presence of this factor can translate structured mRNAs more efficiently. Similarly, these factors could modify the activity of other helicases including eIF4A that is known to unwind the structured regions of mRNAs during translation initiation. An alternative explanation is that one or more of these factors may function to recruit other helicases to the mRNA. Pus2p is known to have an RNA binding and modification activity, among others. A possible explanation is that Pus2 $p$ may bind/modify mRNAs and by doing so it mediates the recruitment and/or binding of other factors to that region. The mechanisms by which these factors can influence the translation of structured mRNAs merits further investigation.

The connection between $\mathrm{LiCl}$ and translation of structured yeast mRNAs observed in the current study may aid in our improved understanding of the BD treatment. It is generally thought that $\mathrm{LiCl}$ has a neuroprotection effect, protecting neurons against apoptosis. In light of the current findings, it is possible that $\mathrm{LiCl}$ exerts its activity by altering the translation of structured mRNAs involved in apoptosis. In future, it would be interesting to investigate the activity of the structured mRNAs involved in apoptosis of the neuron cells for their involvement in the BD progression. It is possible that the expression of these mRNAs may provide an effective target against BD.

\section{Materials and Methods}

\subsection{Strains, Plasmids, Gene Collections, and Cell and DNA Manipulations}

MAT “a” mating strain Y4741 orf $\Delta:: K a n M A X 4$ his3 $\Delta 1$ leu2 $\Delta 0$ met15 $\Delta 0$ ura3 $\Delta 0$ and MAT " $\alpha$ " mating strain, Y7092 can1 $\Delta:: S T E 2 p r-S p \_h i s 5$ lyp1 $\Delta$ his3 $\Delta 1$ leu21 $\Delta 0$ ura3 $\Delta 0$ met15 $\Delta 0$ were used. Deleted mutant strains were obtained from yeast non-essential gene knockout mutant library (YKO) [68]. This library was also used for Synthetic Genetic Analysis (SGA) to make double mutants. Over-expression plasmid of candidate genes were extracted from yeast over-expression collection [69], and yeast PGM2-GFP fusion strain was purchased from Yeast GFP Clone Collection from Thermofisher ${ }^{\circledR}$, Ottawa, Canada which was used for qPCR and western analysis purposes as described previously $[26,27,35]$. The integrity of this strain was confirmed using PCR and chemical sensitivity analyses. Yeast gene deletions in MAT " $\alpha$ " strain were performed by PCR transformation and homologous recombination through Lithium Acetate method as described in 
previous experiments $[65,70]$. Reintroduction of the deleted genes back into their corresponding deletion mutant strains was performed using a modified SGA method and random spore analysis $[37,71]$ by mating the Mat " $a$ " deletion mutant strain, carrying a G418 resistance gene marker in place of the deleted gene with a WT Mat " $\alpha$ " strain carrying a nourseothricin sulfate (clonNAT). In brief, after the sporulation step, spores were allowed to germinate on media containing canavanine and thialysine, to select for MAT "a" haploid progeny. Cells were then transferred to media containing clonNat. Colonies formed from individual cells were tested for sensitivity to G418 using replica plating. Those resistant to clonNAT but sensitive to G418 were selected and tested using PCR analysis to confirm the presence of the target gene in their chromosomes.

p281 construct, carrying a LacZ expression cassette under the control of a gal promoter, was used as our control plasmid. p281-4 with a strong hairpin (5'-GATCCTAGGATCCTAGGATCCTAGG ATCCTAG-3'), inserted upstream of LacZ expression cassette was used as our investigating construct [31]. In order to identify successful transformation in gene knockout experiments, the pAG25 plasmid was used as a DNA template in PCR reactions to amplify a clonNAT resistance gene marker. All plasmids carried an ampicillin resistance gene which was used as a selection marker in $E$. coli DH $5 \alpha$, and a URA3 marker gene for selection in yeast. Kanamycin and NAT drug was used as selectable markers for gene knock out in Mat "a" and Mat " $\alpha$ ", respectively.

p416 construct carries a LacZ expression cassette under the transcriptional control of a gal promoter which was used as our plasmid control in translation activity assays. To generate reporter $\beta$-galactosidase mRNAs under the translational control of complex RNA structures, three different fragments were cloned upstream of the LacZ expression cassette in p416 construct, using the XbaI restriction site. Using this method, three expression constructs were designed as follows: pPGM2 construct which contains the $5^{\prime}$-UTR of PGM2 gene (5'TAATAAGAAAAAGATCAC CAATCTTTCTCAGTAAAAAAAGAACAAAAGTTAACATAACAT $3^{\prime}$ ), pTAR construct which contains the $5^{\prime}$-UTR of HIV-tar1 gene (5' GGGTTCTCTGGTTAGCCAGATCTGAGCCCGGGAGCT CTCTGGCTAGCTAGGGAACCCACTGCTTA AGCCTCAATAAAGCTTGCCTTGAGTGCTTCAAGTA GTGTGTGCC $3^{\prime}$ ) and pRTN which contains the 5'-UTR of FOAP-11 gene (5' GGGATTTTTACA TCGTCTTGGTAAAGGCGTGTGACCCATAGGTTTTTTAGATCAAACACGTCTTTACAAAGGTGA TCTAAGTATCTC $\left.3^{\prime}\right)$.

YP (1\% Yeast extract, $2 \%$ Peptone) or SC (Synthetic Complete) with selective amino acids ( $0.67 \%$ Yeast nitrogen base w/o amino acids, $0.2 \%$ Dropout mix) either with $2 \%$ dextrose or $2 \%$ galactose as a carbon source were used as culture medium for yeast and LB (Lysogeny Broth) was used for E. coli cultures. Two percent agar was used for all solid media. Yeast plasmid extraction was performed using yeast plasmid miniprep kit (Omega Biotek ${ }^{\circledR}$, Norcross, GA, USA) and E. coli plasmid extraction was carried out using GeneJET plasmid miniprep kit (Thermofisher ${ }^{\circledR}$, Ottawa, ON, Canada and Bio-Basics ${ }^{\circledR}$, Toronto, ON, Canada) according to the manufacturers' instructions.

\subsection{Chemical Sensitivity Analysis}

For Chemical sensitivity analysis, yeast cells were grown from independent colonies to saturation for two days at $30^{\circ} \mathrm{C}$ in liquid YPgal. Following incubation, four serial dilutions $\left(10^{-1}\right.$ to $\left.10^{-4}\right)$ of the cell cultures were spotted onto solid media with or without $\mathrm{LiCl}$ treatment. Different concentration of $\mathrm{LiCl}$ (10 $\mathrm{mM}$ and $3 \mathrm{mM}$ ) were tested for growth sensitivity in media containing galactose or glucose as described previously [15,29]. After $48 \mathrm{~h}$, the sensitivity was determined based on colony size and number [65].

For quantification analysis, $100 \mu \mathrm{L}$ of diluted $\left(10^{-4}\right)$ oversaturated cell culture, as described above, was spread on YPgal plates with or without $\mathrm{LiCl}$ treatment. After incubation at $30^{\circ} \mathrm{C}$ for two days, plates were analyzed based on colony numbers. Each experiment was repeated at least three times. $T$-test analysis ( $p$-value $\leq 0.05)$ was used to determine statistically significant results compared to WT control. 


\subsection{Quantitative $\beta$-Galactosidase Assay}

The effect of $5^{\prime}$-UTR regions to mediate translation in different yeast strains was examined using $L a c Z$ reporter systems. This assay was used to evaluate activity of $L a c Z$ cassette in different mutant strains as a reference for translation activity. Quantitative $\beta$-galactosidase assay was performed using ONPG (O-nitrophenyl- $\alpha$-D-galactopyranoside) as described [72,73]. Each experiment was repeated at least three times.

\subsection{Quantitative Real Time PCR ( $q R T-P C R)$}

To determine mRNA level of PGM2 in different deletion mutants, PGM2-GFP yeast strain were grown in YPgal overnight with or without $\mathrm{LiCl}$ treatment. Total RNA was extracted with Qiagen ${ }^{\circledR}$ RNeasy Mini Kit. Complementary DNA (cDNA) was made using iScript Select cDNA Synthesis Kit (Bio-Rad ${ }^{\circledR}$, Mississauga, ON, Canada) according to the manufacturer's instructions. cDNA was then used as a template for quantitative PCR. qPCR was carried out using Bio-Rad ${ }^{\circledR}$ iQ SYBR Green Supermix and the CFX connect real time system (Bio-Rad ${ }^{\circledR}$ ), according to the manufacturers' instructions. PGK1 was used as a constitutive housekeeping gene (internal control). The procedure and data analysis were performed according to MIQE guidelines [74].

The procedure was done in three repeats and $t$-test analysis $(p$-value $\leq 0.05)$ was used to determine statistically significant results. The following primers were used to quantify PGM2 and PGK1 mRNAs, as our positive control in different mutant strains. The primers used are as follows:

PGM2: Forward GGTGACTCCGTCGCAATTAT; Reverse: CGTCGAACAAAGCACAGAAA

PGK1: Forward ATGTCTTTATCTTCAAAGTT; Reverse: TTATTTCTTTTCGGATAAGA

\subsection{Western Blot Analysis}

Western blot analysis was used to investigate the protein content for Pgm2p-GFP fusion protein. Deleted mutant strains with GFP-tagged PGM2 were grown in media treated with and without $\mathrm{LiCl}$ to investigate protein levels of PGM2. Protein extraction was performed as described by Szymanski et al. [75]. Bicinchoninic acid assay (BCA) was performed to estimate protein concentration as described by the manufacturer (Thermo Fisher ${ }^{\circledR}$, Ottawa, ON, Canada). Equal amounts of total protein extract $(50 \mu \mathrm{g})$ were loaded onto a 10\% SDS-PAGE gel, run on Mini-PROTEAN Tetra cell electrophoresis apparatus system (Bio-Rad ${ }^{\circledR}$ ). Proteins were transferred to a nitrocellulose $0.45 \mu \mathrm{m}$ membrane via a Trans-Blot Semi-Dry Transfer (Bio-Rad ${ }^{\circledR}$ ). Mouse monoclonal anti-GFP antibody and anti-Pgk1 (Santa Cruz ${ }^{\circledR}$ ) were used to detect protein levels of Pgm2p-GFP and Pgk1p, respectively. Immunoblots were visualized with chemiluminescent substrates (Bio-Rad ${ }^{\circledR}$ ) on a Vilber Lourmat gel doc Fusion FX5-XT $\left(\right.$ Vilber $\left.^{\circledR}\right)$. Densitometry analysis was carried out using the FUSION FX software (Vilber ${ }^{\circledR}$, Collégien, France). Experiments were repeated at least three times. $T$-test analysis $(p$-value $\leq 0.05)$ was used to determine statistically significant results.

\subsection{Genetic Interaction Analysis}

To investigate Genetic interactions (GI) of our candidate genes NAM7, PUS2, and RPL27B, a SGA was performed in a 384 format as described previously $[26,37,38]$ to make double mutants. GI is presumed when double deletion phenotype causes a more extreme phenotype from single deletion [76], suggesting the deleted genes to be functionally interacting in parallel pathways, causing synthetic sick or lethality. First, the candidate gene is deleted in Mat " $\alpha$ " mating type and then crossed to three sets $(\approx 1000)$ of single mutant Mat "a" mating type. After a few rounds of selection, haploid double gene deletion mutants were selected. Colony size was used as a measure of fitness [37,38]. Colony size of double mutant strains, was compared to that of single mutant strains to detect synthetic sickness or synthetic lethal [34,77]. In brief, the size of individual colonies was measure by an automated software using the corresponding numbers of pixels and normalized to the average size of the colonies on that plate. Normalized colony sizes were then compared and size reductions of 50\% to $95 \%$ were selected. 
This is a very conservative range resulting in the selection of the high confidence hits. This experiment was repeated three times. Only those hits that were observed in at least two repeats were considered as before [26,28].

For conditional SGA analysis, we grew our double mutant strain on media with a sub-inhibitory concentration of $\mathrm{LiCl}(3 \mathrm{mM}$, approximately $1 / 3$ of the concentration used for strain sensitivity analysis) as a stress condition chemical [36] investigating genes that are expressed only under LiCl treatment $[27,50]$.

For PSA analysis, we mated Mat " $\alpha$ " carrying over-expression plasmid of our query gene to entire library of single mutant Mat "a" similar to SGA procedure as mentioned above. In the last step, Mat "a" strains carrying over-expression plasmid are compared to that of Mat "a" carrying a control plasmid [36], both grown in media treated with LiCl. Possible GIs were selected based on gained fitness of mutants when over-expression plasmid of the candidate gene was introduced in the cells, showing compensation of sub-inhibitory effects of $\mathrm{LiCl}$ compared to relevant mutant showing sickness or lethality. In this manner we can propose a functional connection between these two genes $[65,78]$.

\subsection{Genetic Interaction Data Analysis}

Yeast cell fitness is scored and measured based on colony size measurements as described previously [34,77]. We set our threshold at fitness to minimum of $30 \%$ reduction compared to control the mean average of control plate. Each experiment was repeated at least three times, and mutual hits that were observed at least in two repeats were selected. A list of hits then categorized based on their biological process and/or molecular function, with enriched GO terms using Gene Ontology Resources: http://geneontology.org/ (accessed on 18/11/2109), Genemania database http://genemania.org (accessed on 18/11/2019) and profiling of complex functionality http://webclu.bio.wzw.tum.de/profcom/start.php (accessed on 18/11/2019).

\section{Conclusions}

Here, we investigated $\mathrm{LiCl}$ sensitivity for different yeast gene deletion mutant strains, and, in doing so, we reported new activities for NAM7, PUS2, and RPL27B in the translation of structured mRNAs including that for PGM2. Our observations suggest that the translation of structured mRNAs seem to be more complicated than previously thought. Our results also indicate that LiCl sensitivity analysis can be utilized as an effective tool to discover new gene functions in the translation of structured mRNAs.

Supplementary Materials: Supplementary materials can be found at http://www.mdpi.com/1422-0067/21/16/ 5730/s1. Figure S1. LiCl sensitivity analysis for different yeast strains using spot test analysis. Figure S2. The secondary structure of PGM2 5' UTR.

Author Contributions: Conceptualization, A.G.; Data curation, M.H. (Maryam Hajikarimlou); Formal analysis, M.H.(Maryam Hajikarimlou), S.T., B.S. and A.G.; Investigation, M.H. (Maryam Hajikarimlou); Methodology, M.H. (Mohsen Hooshyar), D.B. and H.M.; Project administration, A.G.; Resources, K.O.; Supervision, M.B., M.S., M.H. (Martin Holcik), B.S. and A.G.; Validation, K.H., G.K. and S.K.J.; Visualization, M.H. (Maryam Hajikarimlou); Writing—original draft, M.H. (Maryam Hajikarimlou); Writing—-review \& editing, K.H., G.K., M.S., M.H. (Martin Holcik) and A.G. All authors have read and agreed to the published version of the manuscript.

Funding: This research was funded by Natural Sciences and Engineering Research Council (NSERC), grant number: 123456.

Acknowledgments: This work is dedicated to the loving memory of Minoo Golshani who dedicated her life to helping others.

Conflicts of Interest: The authors declare no conflict of interest. 


\section{Abbreviations}

$\begin{array}{ll}\text { AD } & \text { Alzheimer's Disease } \\ \text { BD } & \text { Bipolar Disorder } \\ \text { LiCl } & \text { Lithium Chloride } \\ \text { WT } & \text { Wild Type } \\ \text { ORF } & \text { Open Reading Frame } \\ \text { ONPG } & \text { O-nitrophenyl- } \alpha \text {-D-galactopyranoside } \\ \text { NAT } & \text { Nourseothricin Sulfate } \\ \text { SGA } & \text { Synthetic Genetic Array } \\ \text { PSA } & \text { Phenotypic Suppression Array } \\ \text { GO } & \text { Gene Ontology } \\ \text { YKO } & \text { yeast non-essential gene knockout mutant library } \\ \text { PI/PKC } & \text { phosphoinositide/Protein Kinase C signaling } \\ \text { UDP-Glucose } & \text { Uridine diphosphate glucose } \\ \text { Ypgal } & \text { Yeast extract, Peptone, and galactose } \\ 5^{\prime}-\text {-UTR } & 5^{\prime} \text {-Untranslated Region }\end{array}$

\section{References}

1. Yan, P.; Xu, D.; Ji, Y.; Yin, F.; Cui, J.; Su, R.; Wang, Y.; Zhu, Y.; Wei, S.; Lai, J. LiCl Pretreatment Ameliorates Adolescent Methamphetamine Exposure-Induced Long-Term Alterations in Behavior and Hippocampal Ultrastructure in Adulthood in Mice. Int. J. Neuropsychopharmacol. 2019, 22, 303-316. [CrossRef] [PubMed]

2. Chiu, C.-T.; Chuang, D.-M. Molecular actions and therapeutic potential of lithium in preclinical and clinical studies of CNS disorders. Pharmacol Ther. 2011, 128, 281-304. [CrossRef] [PubMed]

3. Ariyasinghe, D.; Perera, S.R. The role of lithium in the treatment of bipolar disorder, Sri Lanka. J. Psychiatry 2018, 28-30. [CrossRef]

4. Hull, M.; Lee, E.; Lee, T.; Anand, N.; Lalone, V.; Parameswaran, N. Lithium chloride induces TNF $\alpha$ in mouse macrophages Via MEK-ERK-dependent pathway. J. Cell. Biochem. 2014, 115, 71-80. [CrossRef]

5. Mu, F.; Huang, J.; Xing, T.; Jing, Y.; Cui, T.; Guo, Y.; Yan, X.; Li, H.; Wang, N. The Wnt/ $\beta$-catenin/Lef1 pathway promotes cell proliferation at least in part through direct upregulation of miR-17-92 cluster. Front. Genet. 2019, 10, 1-12. [CrossRef]

6. Won, E.; Kim, Y. An Oldie but Goodie: Lithium in the Treatment of Bipolar Disorder through Neuroprotective and Neurotrophic Mechanisms. Int. J. Mol. Sci. 2017, 18, 2679. [CrossRef]

7. Sofola-adesakin, O.; Castillo-quan, J.; Rallis, C.; Tain, L.; Bjedov, I.; Rogers, I.; Li, L.; Martinez, P.; Khericha, M.; Cabecinha, M.; et al. Lithium suppresses A $\beta$ pathology by inhibiting translation in an adult Drosophila model of Alzheimer's disease. Front. Aging Neurosci. 2014, 6, 1-10. [CrossRef]

8. Zhang, J. Lithium chloride promotes proliferation of neural stem cells in vitro, possibly by triggering the Wnt signaling pathway. Taylor Fr. Gr. 2019, 23, 32-41. [CrossRef]

9. Williams, R.S.; Harwood, A. Lithium therapy and signal transduction. Trends Pharmacol. Sci. 2000, $21,61-64$. [CrossRef]

10. Hampel, H.; Ewers, M.; Bürger, K.; Annas, P.; Mörtberg, A.; Bogstedt, A.; Frölich, L.; Schröder, J.; Schönknecht, P.; Riepe, M.W.; et al. Lithium trial in Alzheimer's disease: A randomized, single-blind, placebo-controlled, multicenter 10-week study. J. Clin. Psychiatry. 2009, 70, 922-931. [CrossRef]

11. Castillo-Quan, J.; Li, L.; Kinghorn, K.; Hardy, J.; Bjedov, I.; Partridge, L. Lithium Promotes Longevity through GSK3/NRF2- Dependent Hormesis Lithium Promotes Longevity. Cell Rep. 2016, 15, 638-650. [CrossRef] [PubMed]

12. Yang, D.; Song, L.; Hu, J.; Yin, W.; Li, Z.; Chen, Y.; Su, X.; Wang, R.; Hu, Z. Biochemical and Biophysical Research Communications Enhanced tolerance to $\mathrm{NaCl}$ and $\mathrm{LiCl}$ stresses by over-expressing Caragana korshinskii sodium/proton exchanger 1 (CkNHX1) and the hydrophilic $\mathrm{C}$ terminus is required for the activity of CkNHX1 in Atsos3. Biochem. Biophys. Res. Commun. 2012, 417, 732-737. [CrossRef] [PubMed]

13. Lenox, R.H.; Wang, L. Molecular basis of lithium action: Integration of lithium-responsive signaling and gene expression networks. Mol. Psychiatry. 2003, 8, 135-144. [CrossRef] 
14. Montero-Lomelí, M.; Morais, B.L.B.; Figueiredo, D.L.; Neto, D.C.S.; Martins, J.R.P.; Masuda, C.A. The initiation factor eIF4A is involved in the response to lithium stress in Saccharomyces cerevisiae. J. Biol. Chem. 2002, 277, 21542-21548. [CrossRef]

15. Masuda, C.A.; Xavier, M.A.; Mattos, K.A.; Galina, A.; Montero-Lomeli, M. Phosphoglucomutase Is an in Vivo Lithium Target in Yeast. Biol. Chem. 2001, 276, 37794-37801. [CrossRef]

16. Liu, J.; Zhang, G.C.; Kong, I.; Yun, E.; Zheng, J.; Kweon, D.; Jin, Y. A mutation in PGM2 causing inefficient Galactose metabolism in the Probiotic Yeast Saccharomyces boulardii. Appl. Environ. Microbiol. 2018, 84, 1-12. [CrossRef] [PubMed]

17. Bergkessel, M.; Whitworth, G.; Guthrie, C. Diverse environmental stresses elicit distinct responses at the level of pre-mRNA processing in yeast. RNA 2011, 17, 1461-1478. [CrossRef]

18. Dichtl, B.; Stevens, A.; Tollervey, D. Lithium toxicity in yeast is due to the inhibition of RNA processing enzymes. EMBO J. 1997, 16, 7184-7195. [CrossRef]

19. Asensio, J.; Ruiz-Argüeso, T. Rodríguez-Navarro, A. Sensitivity of yeasts to lithium. Antonie Van Leeuwenhoek. 1976, 42, 1-8. [CrossRef]

20. Zhao, J.; Lin, W.; Ma, X.; Lu, Q.; Ma, X.; Bian, G.; Jiang, L. The protein kinase Hal5p is the high-copy suppressor of lithium-sensitive mutations of genes involved in the sporulation and meiosis as well as the ergosterolbiosynthesis in Saccharomyces cerevisiae. Genomics 2010, 95, 290-298. [CrossRef]

21. Asghar, F.; Yan, H.; Jiang, L. The putative transcription factor CaMaf1 controls the sensitivity to lithium and rapamycin and represses RNA polymerase III transcription in Candida albicans. FEMS Yeast Res. 2018, 18, 1-9. [CrossRef] [PubMed]

22. Lopez, F.; Leube, M.; Gil-Mascarell, R.; Navarro-Aviñó, J.P.; Serrano, R. The yeast inositol monophosphatase is a lithium- and sodium-sensitive enzyme encoded by a non-essential gene pair. Mol. Microbiol. 1999, 31, 1255-1264. [CrossRef] [PubMed]

23. Hajikarimlou, M.; Moteshareie, H.; Omidi, K.; Hooshyar, M.; Shaikho, S.; Kazmirchuk, T.; Burnside, D.; Takallou, S.; Zare, N.; Jagadeesan, S.K.; et al. Sensitivity of yeast to lithium chloride connects the activity of YTA6 and YPR096C to translation of structured mRNAs. PLoS ONE 2020, 15, e0235033. [CrossRef] [PubMed]

24. Du, J.; Cao, C.; Jiang, L. Genome-scale genetic screen of lead ion-sensitive gene deletion mutations in Saccharomyces cerevisiae. Gene 2015, 563, 155-159. [CrossRef] [PubMed]

25. Zhao, Y.; Cao, C.; Liu, Y.; Wang, J.; Li, S.; Li, J.; Deng, Y. Genetic analysis of oxidative and endoplasmic reticulum stress responses induced by cobalt toxicity in budding yeast. Biochim. Biophys. Acta Gen. Subj. 2020, 1864, 129516. [CrossRef]

26. Moteshareie, H.; Hajikarimlou, M.; Indrayanti, A.M.; Burnside, D.; Paula, A.; Id, D.; Lettl, C.; Ahmed, D.; Omidi, K.; Id, T.K.; et al. Heavy metal sensitivities of gene deletion strains for ITT1 and RPS1A connect their activities to the expression of URE2, a key gene involved in metal detoxification in yeast. PLoS ONE 2018, 13, e0198704. [CrossRef]

27. Alamgir, M.; Jessulat, M.; Azizi, A.; Golshani, A. Chemical-genetic profile analysis of five inhibitory compounds in yeast. BMC Chem. Biol. 2010, 10. [CrossRef]

28. Omidi, K.; Jessulat, M.; Hooshyar, M.; Burnside, D.; Schoenrock, A.; Kazmirchuk, T.; Hajikarimlou, M.; Daniel, M.; Moteshareie, H.; Bhojoo, U.; et al. Uncharacterized ORF HUR1 influences the efficiency of non-homologous end-joining repair in Saccharomyces cerevisiae. Gene 2018, 639, 128-136. [CrossRef]

29. Bro, C.; Regenberg, B.; Lagniel, G.; Labarre, J.; Montero-Lomelí, M.; Nielsen, J. Transcriptional, proteomic, and metabolic responses to lithium in galactose-grown yeast cells. J. Biol. Chem. 2003, 278, 32141-32149. [CrossRef]

30. Nagalakshmi, U.; Wang, Z.; Waern, K.; Shou, C.; Raha, D.; Gerstein, M.; Synder, M. The Transcriptional Landscape of the Yeast Genome Defined by RNA Sequencing. Science 2008, 320, 1344-1350. [CrossRef]

31. Altmann, M.; Müller, P.; Wittmer, B.; Ruchti, F.; Lanker, S.; Trachsel, H. A Saccharomyces cerevisiae homologue of mammalian translation initiation factor $4 \mathrm{~B}$ contributes to RNA helicase activity. EMBO J. 1993, 12, 3997-4003. [CrossRef] [PubMed]

32. Bolinger, C.; Sharma, A.; Singh, D.; Yu, L. RNA helicase A modulates translation of HIV-1 and infectivity of progeny virions. Nucleic Acids Res. 2010, 38, 1686-1696. [CrossRef]

33. Washietl, S.; Hofacker, I.L.; Lukasser, M.; Hüttenhofer, A.; Stadler, P.F. Mapping of conserved RNA secondary structures predicts thousands of functional noncoding RNAs in the human genome. Nat. Biotechnol. 2005, 23, 1383-1390. [CrossRef] [PubMed] 
34. Wagih, O.; Usaj, M.; Baryshnikova, A.; Vandersluis, B.; Kuzmin, E.; Costanzo, M.; Myers, C.L.; Andrews, B.J.; Boone, C.M.; Parts, L. SGAtools: One-stop analysis and visualization of array-based genetic interaction screens. Nucleic Acids Res. 2013, 41, 591-596. [CrossRef] [PubMed]

35. Jessulat, M.; Malty, R.H.; Nguyen-tran, D.; Deineko, V.; Aoki, H.; Vlasblom, J.; Omidi, K. Spindle Checkpoint Factors Bub1 and Bub2 Promote DNA DoubleStrand Break Repair by Nonhomologous End Joining. Mcb 2015, 35, 2448-2463. [CrossRef]

36. Samanfar, B.; Shostak, K.; Moteshareie, H.; Hajikarimlou, M.; Shaikho, S.; Omidi, K.; Hooshyar, M.; Burnside, D.; Márquez, I.G.; Kazmirchuk, T.; et al. The sensitivity of the yeast, Saccharomyces cerevisiae, to acetic acid is influenced by DOM34 and RPL36A. PeerJ 2017, 2017. [CrossRef]

37. Tong, A.; Evangelista, M.; Parsons, A.B.; Xu, H.; Bader, G.D.; Page, N.; Robinson, M.; Raghibizadeh, S.; Hogue, C.W.V.; Bussey, H.; et al. Systematic Genetic Analysis with Ordered Arrays of Yeast Deletion Mutants. Science 2001, 294, 2364-2369. [CrossRef]

38. Toufighi, K.; Youn, J.; Ou, J.; Luis, B.S.; Hibbs, M.; Hess, D.; Gingras, A.; Bader, G.D.; Troyanskaya, O.G.; Brown, G.W.; et al. Quantitative analysis of fitness and genetic interactions in yeast on a genome scale. Nat. Methods 2011, 7, 1017-1024. [CrossRef]

39. Karásková, M.; Gunis, S.; Herrmannová, A.; Wagner, S.; Munzarová, V. Functional Characterization of the Role of the N-terminal Domain of the c/Nip1 Subunit of Eukaryotic Initiation Factor 3 (eIF3) in AUG Recognition. JBC 2012, 287, 28420-28434. [CrossRef]

40. Firczuk, H.; Kannambath, S.; Pahle, J.; Claydon, A.; Beynon, R.; Duncan, J.; Westerhoff, H.; Mendes, P.; McCarthy, J.E. An in vivo control map for the eukaryotic mRNA translation machinery. Mol. Syst. Biol. 2013, 9, 1-13. [CrossRef]

41. Pisareva, V.P.; Pisarev, A.V. DHX29 and eIF3 cooperate in ribosomal scanning on structured mRNAs during translation initiation. RNA 2016, 22, 1859-1870. [CrossRef] [PubMed]

42. Cuchalova, L.; Kouba, T.; Herrmannova, A.; Danyi, I.; Chiu, W.-L.; Valasek, L. The RRM of eIF3g is required for resumption of scanning of post-termination ribosomes for reinitiation on GCN4 and together with eIF3i stimulates linear scanning. Mol. Cell. Biol. 2010, 30, 4671-4686. [CrossRef] [PubMed]

43. Valášek, L.; Phan, L.; Schoenfeld, L.W.; Valášková, V.; Hinnebusch, A.G. Related eIF3 subunits TIF32 and HCR1 interact with an RNA recognition motif in PRT1 required for eIF3 integrity and ribosome binding. EMBO J. 2001, 20, 891-904. [CrossRef] [PubMed]

44. Blasco-moreno, B.; De Campos-mata, L.; Böttcher, R.; García-martínez, J.; Jung, J.; Nedialkova, D.D.; Chattopadhyay, S.; Gas, M.; Oliva, B.; Pérez-ortín, J.E.; et al. The exonuclease Xrn1 activates transcription and translation of mRNAs encoding membrane proteins. Nat. Commun. 2019, 1-15. [CrossRef]

45. Hinnebusch, A.G. Molecular Mechanism of Scanning and Start Codon Selection in Eukaryotes. Microbiol. Mol. Biol. Rev. 2011, 75, 434-467. [CrossRef]

46. Sen, N.D.; Zhou, F.; Ingolia, N.T.; Hinnebusch, A.G. Genome-wide analysis of translational efficiency reveals distinct but overlapping functions of yeast DEAD-box RNA helicases Ded1 and eIF4A. Genome Res. 2015, 25, 1196-1205. [CrossRef] [PubMed]

47. Murvin, M.; Banruo, Y.; Alec, D.; Christian, F.; Angie, F. Methylation of Ded1 Affects Its Role in Translation. FASEB J. 2019. Available online: https://www.fasebj.org/doi/abs/10.1096/fasebj.2019.33.1_supplement.629.5 (accessed on 20 January 2020). [CrossRef]

48. Minshall, N.; Kress, M.; Weil, D.; Standart, N. Role of p54 RNA Helicase Activity and Its C-terminal Domain in Translational Repression, P-body Localization and Assembly. Mol. Biol. Cell. 2009, 20, 2464-2472. [CrossRef] [PubMed]

49. Suzuki, Y.; Minami, M.; Suzuki, M.; Abe, K.; Zenno, S.; Tsujimoto, M.; Matsumoto, K.; Minami, Y. The Hsp90 Inhibitor Geldanamycin Abrogates Colocalization of eIF4E and eIF4E-Transporter into Stress Granules and Association of eIF4E with eIF4G. J. Biol. Chem. 2009, 284, 35597-35604. [CrossRef] [PubMed]

50. Omidi, K.; Hooshyar, M.; Jessulat, M.; Samanfar, B.; Sanders, M.; Burnside, D.; Pitre, S.; Schoenrock, A.; Xu, J.; Babu, M.; et al. Phosphatase Complex Pph3/Psy2 Is Involved in Regulation of Efficient Non-Homologous End-Joining Pathway in the Yeast Saccharomyces cerevisiae. PLoS ONE 2014, 9, e87248. [CrossRef]

51. Fischer, N.; Weis, K. The DEAD box protein Dhh1 stimulates the decapping enzyme Dcp1. EMBO J. 2002, 21, 2788-2797. [CrossRef] [PubMed]

52. Carroll, J.S.; Munchel, S.E.; Weis, K. The DExD/H box ATPase Dhh1 functions in translational repression, mRNA decay, and processing body dynamics. Cell Biol. 2011, 194, 527-537. [CrossRef] [PubMed] 
53. Blewett, N.H.; Goldstrohm, A.C. A Eukaryotic Translation Initiation Factor 4E-Binding Protein Promotes mRNA Decapping and Is Required for PUF Repression. Mcb 2012, 32, 4181-4194. [CrossRef] [PubMed]

54. Li, X.; Ohmori, T.; Irie, K.; Kimura, Y.; Suda, Y.; Mizuno, T.; Ire, K. Different Regulations of ROM2 and LRG1 Expression by Ccr4, Pop2, and Dhh1 in the Saccharomyces cerevisiae Cell Wall Integrity Pathway. MSphere 2016, 1. [CrossRef] [PubMed]

55. Coordes, B. Ctk1 Function is Ccrucial for Efficient Translation Initiation and Interacts with the mRNP Processing Factor Npl3. Ph.D. Thesis, University of Munich, Munich, Germany, 2011. Available online: https://edoc.ub.uni-muenchen.de/13203/1/Coordes_Britta.pdf (accessed on 20 January 2020).

56. Coordes, B.; Brünger, K.M.; Burger, K.; Soufi, B.; Horenk, J.; Eick, D. Ctk1 Function Is Necessary for Full Translation Initiation Activity in Saccharomyces cerevisiae. Am. Soc. Microbiol. 2015, 14, 86-95. [CrossRef] [PubMed]

57. Boone, C.; Bussey, H.; Andrews, B.J. Exploring genetic interactions and networks with yeast. Nat. Rev. Genet. 2007, 8, 437-449. [CrossRef]

58. Douglas, A.C.; Smith, A.M.; Sharifpoor, S.; Yan, Z.; Durbic, T.; Heisler, L.E.; Lee, A.Y.; Ryan, O.; Göttert, H.; Surendra, A.; et al. Functional Analysis With a Barcoder Yeast Gene Overexpression System. G3 Genes Genomes Genet. 2012, 2, 1279-1289. [CrossRef]

59. Kodama, H.; Ito, K.; Nakamura, Y. The role of N-terminal domain of translational release factor eRF3 for the control of functionality and stability in S. cerevisiae. Genes Cells 2007, 12, 639-650. [CrossRef]

60. Xiao, R.; Gao, Y.; Shen, Q.; Li, C.; Chang, W.; Chai, B. Polypeptide chain release factor eRF3 is a novel molecular partner Of survivin. Cell Biol. Int. 2013, 37, 359-369. [CrossRef]

61. Reineke, L.C.; Cao, Y.; Baus, D.; Hossain, N.M.; Merrick, W.C. Insights into the role of yeast eiF2A in Ires-Mediated translation. PLoS ONE 2011, 6. [CrossRef]

62. Rutter, J.; Probst, B.L.; Mcknight, S.L. Coordinate Regulation of Sugar Flux and Translation by PAS Kinase. Cell 2002, 111, 17-28. [CrossRef]

63. Jeon, S.; Lim, S.; Ha, J.; Kim, J. Identification of Psk2, Skp1, and Tub4 as trans-acting factors for uORF-containing ROK1 mRNA in Saccharomyces cerevisiae. Microbiology 2015, 53, 616-622. [CrossRef] [PubMed]

64. Alamgir, M.; Eroukova, V.; Jessulat, M.; Xu, J.; Golshani, A. Chemical-genetic profile analysis in yeast suggests that a previously uncharacterized open reading frame, YBR261C, affects protein synthesis. BMC Genom. 2008, 9, 583. [CrossRef] [PubMed]

65. Samanfar, B.; Omidi, K.; Hooshyar, M.; Laliberte, B.; Alamgir, M.; Seal, A.J.; Ahmed-Muhsin, E.; Viteri, D.F.; Said, K.; Chalabian, F.; et al. Large-scale investigation of oxygen response mutants in Saccharomyces cerevisiae. Mol. Biosyst. 2013, 9, 1351-1359. [CrossRef] [PubMed]

66. Yan, Z.; Costanzo, M.; Heisler, L.E.; Paw, J.; Kaper, F.; Andrews, B.J.; Boone, C.; Giaever, G.; Nislow, C. Yeast Barcoders: A chemogenomic application of a universal donor-strain collection carrying bar-code identifiers. Nat. Methods 2008, 5, 719-725. [CrossRef] [PubMed]

67. Yan, Z.; Berbenetz, N.M.; Giaever, G.; Nislow, C. Precise gene-dose alleles for chemical genetics. Genetics 2009, 182, 623-626. [CrossRef] [PubMed]

68. Giaever, G.; Nislow, C. The Yeast Deletion Collection: A Decade of Functional Genomics. Genetics 2014, 197, 451-465. [CrossRef]

69. Gelperin, D.M.; White, M.A.; Wilkinson, M.L.; Kon, Y.; Kung, L.A.; Wise, K.J.; Lopez-hoyo, N.; Jiang, L.; Piccirillo, S.; Yu, H.; et al. Biochemical and genetic analysis of the yeast proteome with a movable ORF collection. Genes Dev. 2005, 2816-2826. [CrossRef]

70. Karlsson-rosenthal, C.; Millar, J.B.A. Cdc25: Mechanisms of checkpoint inhibition and recovery. Trends Cell Biol. 2006, 16. [CrossRef]

71. Tong, A.H.; Lesage, G.; Bader, G.D.; Ding, H.; Xu, H.; Xin, X.; Young, J.; Berriz, G.F.; Brost, R.L.; Chang, M.; et al. Global mapping of the yeast genetic interaction network. Science 2004, 303, 808-813. [CrossRef]

72. Krogan, N.J.; Kim, M.; Tong, A.; Golshani, A.; Cagney, G.; Canadien, V.; Richards, D.P.; Beattie, B.K.; Emili, A.; Boone, C.; et al. Methylation of Histone $\mathrm{H} 3$ by Set2 in Saccharomyces cerevisiae Is Linked to Transcriptional Elongation by RNA Polymerase II. Mcb 2003, 23, 4207-4218. [CrossRef]

73. Stansfield, I.; Akhmaloka, M.; Tuite, F. A mutant allele of the SUP45 (SAL4) gene of Saccharomyces cerevisiae shows temperature-dependent aUosuppressor and omnipotent suppressor phenotypes. Curr. Genet. 1995, 27, 417-426. [CrossRef] [PubMed] 
74. Bustin, S.A.; Benes, V.; Garson, J.A.; Hellemans, J.; Huggett, J.; Kubista, M.; Mueller, R.; Nolan, T.; Pfaffl, M.W.; Shipley, G.L.; et al. The MIQE guidelines: Minimum information for publication of quantitative real-time PCR experiments. Clin. Chem. 2009, 55, 611-622. [CrossRef] [PubMed]

75. Szymanski, E.P.; Kerscher, O. Budding Yeast Protein Extraction and Purification for the Study of Function, Interactions, and Post-translational Modifications. J. Vis. Exp. 2013, 80, 1-9. [CrossRef] [PubMed]

76. Baryshnikova, A.; Costanzo, M.; Dixon, S.; Vizeacoumar, F.J.; Myers, C.L.; Andrews, B.; Boone, C. Synthetic Genetic Array (SGA) Analysis in Saccharomyces Cerevisiae and Schizosaccharomyces Pombe, 2nd ed.; Elsevier Inc.: Amsterdam, The Netherlands, 2010. [CrossRef]

77. Memarian, N.; Jessulat, M.; Alirezaie, J.; Mir-Rashed, N.; Xu, J.; Zareie, M.; Smith, M.; Golshani, A. Colony size measurement of the yeast gene deletion strains for functional genomics. BMC Bioinform. 2007, 8. [CrossRef]

78. Samanfar, B.; Tan, L.H.; Shostak, K.; Chalabian, F.; Wu, Z.; Alamgir, M.; Sunba, N.; Burnside, D.; Omidi, K.; Hooshyar, M.; et al. A global investigation of gene deletion strains that affect premature stop codon bypass in yeast, Saccharomyces cerevisiae. Mol. Biosyst. 2014, 10, 916-924. [CrossRef]

(C) 2020 by the authors. Licensee MDPI, Basel, Switzerland. This article is an open access article distributed under the terms and conditions of the Creative Commons Attribution (CC BY) license (http://creativecommons.org/licenses/by/4.0/). 